\title{
Comparative Effect of Horse Dung and Pig Dung on The Early Growth of Nauclea diderrichii (De Wild) Seedlings
}

\section{*AYENI, OD; OJO, MO; OKUMODI, BO}

\author{
Forestry Research Institute of Nigeria, Ibadan \\ *Corresponding Author Email: ayeniolatunji62@yahoo.com; Tel: +2348036673441
}

\begin{abstract}
The research work examined the effect of horse dung and pig dung on the early growth of Nauclea diderrichii seedling. The experiment was carried out at the back of library of Federal College of Forestry, Ibadan. The experiment consisted of five treatments which were replicated nine times in a completely Randomized design (CRD). The following materials were used: Topsoil, Polythenepot, seeds of Nauclea diderrichii, Horse dung and pig dung, sieve, wheel barrow, venier caliper, ruler, field record book and pen. Data on the number of stem girth, height, leave production and leave area were recorded fortnightly starting from a week after transplanting. The data collected were analyzed through Analysis of Variance (ANOVA). The result revealed that $15 \mathrm{~g}$ of horse dung $+2 \mathrm{~kg}$ of top soil had the highest mean number of height value of $12.49 \mathrm{~cm}$ followed by $10 \mathrm{~kg}$ of horse dung $+2 \mathrm{~kg}$ of topsoil, $(10.15 \mathrm{~cm})$. While topsoil only had the least mean number of height $(8.25 \mathrm{~cm})$. The result further showed the highest mean stem girth $(0.30 \mathrm{~cm})$ followed by $0.27 \mathrm{~cm}$ and produced least mean stem girth of $0.24 \mathrm{~cm}$ in treatments T12, T1 and T5 respectively. Also, in the leaf production the result revealed that $15 \mathrm{~g}$ of horse dung $+2 \mathrm{~kg}$ of topsoil had the highest mean number of $16.69 \mathrm{~cm}$ followed by treatment one $12,56 \mathrm{~cm}$ and topsoil only produce the least mean leaf production of $9.40 \mathrm{~cm}$. The result further showed highest mean leave area $\left(134.50 \mathrm{~cm}^{2}\right)$ followed by treatment one $124.60 \mathrm{~cm}^{2}$ and (T5) produced the least mean leaf area of $108.06 \mathrm{~cm}^{2}$. Analysis of variance (ANOVA) for plant height, stem girth, leaf production and leaf area also indicated that the treatment applied Nauclea diderrichii seedlings showed no significant effect. Generally $15 \mathrm{~g}$ of horse dung $+2 \mathrm{~kg}$ of topsoil produced the best result in terms of plant height, stem girth, leaf production and leave area of Nuclea diderrichii seedlings, hence treatment two (T2) is best suitable for raising Nuclea diderrichii seedlings.
\end{abstract}

\section{DOI:https://dx.doi.org/10.4314/jasem.v25i3.19}

Copyright: Copyright (C) 2021 Ayeni et al. This is an open access article distributed under the Creative Commons Attribution License (CCL), which permits unrestricted use, distribution, and reproduction in any medium, provided the original work is properly cited.

Dates: Received: 12 December 2020; Revised: 26 January 2021; Accepted: 12 February 2021

Keywords: Forest, Horse dung, Pig dung, Nauclea diderrichii

Natural and planted forests represent more than natural capital. They contribute to human capital by providing a range of goods, such as wild game, fruits or traditional medicines that improve health (Smith and Scherr, 2002).Forest plays critical roles in maintaining and providing important ecosystem services and function (Nadrowski, 2010). In recent decades, there has been an extensive loss-of- tropical forests, driven primarily by the expansion of agricultural land (Hansen et. al, 2013), the diversity of forested ecosystem has important consequence on carbon storage, decomposition or mineral cycling, nutrients acquisition, committee of biota, growth and productivity ((Amishai, et. al,. 2009)species Nauclea diderrichii (Opepe) is an evergreen tree, which originated from tropical rain forest of west Africa and extends to southern Angola. The common name is called Badi. It is a very large evergreen tree with a dense, broad, spherical crown; usually growing 40 meters tall, exceptionally to 50 meters (Burkil, 2004). The tree is harvested from the wild for local use as a medicine and source of wood. The tree is heavily exploited from the wild for its timber. Regeneration is good in large canopy gaps but the species is outcompeted by other pioneers after clear-felling. As a result, the tree has been listed as vulnerable (IUCN, 2009). It has been grown in taugya plantation within its natural distribution. It has been grown in Nigeria since 1918 as a nurse species for many valuable mahoganies (Khaya spp) and has a useful species in its own right plantation. Apart from timber products and services, the leaves and bark of Nauclea diderrichii are used in treating several ailment in most rural communities in Ghana (Manns and Bremer, 2010). However, over exploitation coupled with paucity in natural regeneration threatens these (Adu-Bredu and Hagihara 2003). Attempts to grow Nauclea diderrichii in plantations have generally been impaired by attacks from Orymophoea mediforeata (Lepidoptera: Noctuidae) and lamprosema. Studies have shown that these specialist insect herbivores can cause serious damages to, especially young plantation of Nauclea diderrichii (Bosu, 2013). Caterpillars of $O$ medioforeata infest terminal shoots by boring into nodes especially the apical shoots and heavy multiple attacks usually lead to death. Intensive agriculture is 
one of the main activities in tropical countries and especially in Southwest Nigeria in particular, causes for relatively high fertilizer and pesticides inputs. Intensive use of soil for years, together with inadequate production technologies like continuous soil removal and the widespread use of pesticides and fertilizer have created in many cases major problems of pollution and soil degradation. Thus, the need to minimize environmental impact without reducing yields make it imperative to look for best bet alternatives that achieve a suitable and sustainable agricultural production. Organic manures are natural products used by farmers to enhance sustainable crop production. Almost all farmers in Senegal use organic fertilizer or manures. They apply them depending on the type of crop and the season (Niassy et. al., 2010). They often use Ovine (sheep), horse, poultry, peasant hull and cattle manure, used either alone or in combination. Some farmers also use fish manure for particular crops. Selection of manures depends on the type of crop, the variety and the season. It also depend on the chemistry of the soil, and the farmers previous experience and observation (Niassy et. al., 2010).There are numbers of organic manures like farm yard manure, green manures, compost prepared from crop residues and other farm wastes and biological wastes - animal bones, slaughter house refuse. Organic manure increase the organic matter in the soil; It releases the plant food in available form for the use of crops; it enables the soil to hold more water and also help to improve the drainage in clay soils; and also provide organic acids that help to dissolve soil nutrient and make them available for plants. Horse manure is a good source of nutrients and a popular addition to many home gardens. It contributes to increasing soil fertility, regeneration and maintenance of high quality yields. It averts the negative effects of salinity. This manure improves the capacity of soil water retention. Horse dung manure considerably increases crop yield and is long lasting in the soil. Composting horse manure can help your compost pile become super charged. Readily available in many rural areas or through reputable suppliers, horse manure makes a suitable and inexpensive fertilizer for plant. Horse manure can give new plants a jump start while providing essential nutrients for continual growth. Pig manure organic fertilizer production line has the advantages of compact layout, advance technology, stable operation, easy maintenance; its material has a wide adaptability and is suitable for organic compound fertilizer and biological organic fertilizer with various proportions, which provide nutrient for growth of plant and grow and improve soil. According to Greenland (1997), the significance of organic material in tropical soil is greater than any other soil characteristics apart from moisture. Jackson (1990) emphasized that the maintenance of organic matter is of fundamental importance to productivity to tropical soil.

\section{MATERIALS AND METHOD}

Study Area: The experiment was sited at the back of library of the Federal College of Forestry, Jericho, Ibadan south west local government area of Oyo state. The area lies between the latitude of $7^{\circ} 26 \mathrm{~N}$ and longitudes $3^{\circ} 54 \mathrm{E}$. The climatic condition of the area is tropically dominated by rainfall pattern ranging from $1400 \mathrm{~mm}-1500 \mathrm{~mm}$. the average temperature is about $26^{\circ} \mathrm{C}$, the ecological climate of the area experience rainfall with two-distinct season usually from AprilOctober (FRIN, 2019).

Materials Used For the Experiment: The material used for this project work were as follow: topsoil, polythene pot (medium size), seeds of nauclea diderrichii, sieve, wheel barrow, shovel, watering can, river sand, germination box, venier caliper, transparent measuring ruler $(30 \mathrm{~cm})$, horse dung and pig dung, paper and biro. Procurement of Materials: The seeds of Nauclea diderrichii were collected from Aba-agbo Village on the matured tree of Nauclea diderrichii in Oluyole local Government area of Oyo State. The top soil used was collected at the back of Federal College of Forestry School library. Horse dung was collected at Polo club Eleyele Ibadan, while the pig dung was collected at the piggery house Orita Aperin, Ibadan. Polythene pot $14 \mathrm{~cm} \times 7 \mathrm{~cm}$ were purchased from Dugbe market.

Propagation: Horse dung and pig dung were air dried for five days before sieved to make it easy mixing with the top soil. Weighing balance was used to weigh both the horse dung and pig dung. This was taken to the Soil Laboratory section of Institute of Agricultural Research and Training (I.A.R\&T). The seeds were sown in a germination box on $6^{\text {th }}$ April, 2013 and germination of seed was noticed six days after planting. On the third week of seed sown, the seeds of Nauclea diderrichii were sown in a germination box filled with sterilized river sand for three weeks and after germination they were transplanted into a small size of polythene pot which were filled with $2 \mathrm{~kg}$ of top soil and sample of each treatment were taken to department of Agronomy University of Ibadan for chemical analysis and then $10 \mathrm{~kg}$ and $15 \mathrm{~kg}$ of each treatment were added to $2 \mathrm{~kg}$ of top soil. The reading commenced immediately after one week.

Experimental design: The experimental design used was completely randomized design (CRD), which comprised of (5) five treatments with nine (9) replicates. 
Table 1.Experiment layout

\begin{tabular}{|c|c|c|c|c|c|c|c|c|c|}
\hline $\mathrm{T} 1=$ & T1R4 & T1R3 & T1R5 & T1R1 & T1R7 & T1R6 & $\mathrm{T} 1 \mathrm{R} 2$ & T1R9 & T1R8 \\
\hline $\mathrm{T} 2=$ & $\mathrm{T} 2 \mathrm{R} 3$ & T2R4 & $\mathrm{T} 2 \mathrm{R} 2$ & T2R6 & T2R8 & $\mathrm{T} 2 \mathrm{R} 9$ & $\mathrm{~T} 2 \mathrm{R} 1$ & T2R5 & T1R8 \\
\hline $\mathrm{T} 3=$ & T3R2 & T3R4 & T3R8 & T3R6 & T3R3 & T3R9 & T3R5 & T3R1 & T3R7 \\
\hline $\mathrm{T} 4=$ & T4R8 & T4R4 & T4R6 & T4R9 & T4R1 & T4R3 & T4R7 & T4R2 & T4R5 \\
\hline $\mathrm{T} 5=$ & T5R9 & T5R4 & T5R6 & T5R1 & T5R7 & T5R3 & T5R5 & T5R2 & T5R8 \\
\hline
\end{tabular}

Key:T1 = $10 \mathrm{~g}$ of horse dung $+2 \mathrm{~kg}$ of top soil; $T 2=15 \mathrm{~g}$ of horse dung $+2 \mathrm{~kg}$ of top soil; $T 3=10 \mathrm{~g}$ of pig dung $+2 \mathrm{~kg}$ of top soil; $T 4=15 \mathrm{~g}$ of pig dung $+2 \mathrm{~kg}$ of top soil; $T 5=\operatorname{control}(2 \mathrm{~kg}$ of top soil)

Data collection: Data collection commences a week after transplanting of seedling and subsequent data obtained weekly. Parameters assessed include Plant height: each seedling was measured by use of measuring ruler graduated in $\mathrm{cm}$. Leaf production: the leaflets were counted and recorded. Stem diameter: the diameter was obtained by measuring the stem with aid of venier caliper. Leaf area: length and breadth of leaves were measured from the top, middle, and basal height with aid of metric ruler.

Data Analysis: Descriptive statistical tools were used to compare the treatment means in each of the parameter measured while Least Significant Difference was used to test the level of significance among different treatments at $5 \%$ probability. At the end of experiment data was subjected to analysis of variance (ANOVA).

\section{RESULTS AND DISCUSSION}

Table one presents the experimental layout of the treatments; Treatment $(\mathrm{T}) \mathrm{T}_{1}(10 \mathrm{~g}$ horse dung $+2 \mathrm{~kg}$ of top soil), $\mathrm{T}_{2}$ (15g horse dung $+2 \mathrm{~kg}$ of top soil) $\mathrm{T}_{3}(10 \mathrm{~g}$ pig dung $+2 \mathrm{~kg}$ of top soil), $\mathrm{T}_{4}$ (15g PIG dung $+2 \mathrm{~kg}$ of top soil) and $\mathrm{T}_{5}(2 \mathrm{~kg}$ of top soil which is the control). Table 2 presents the chemical composition of the organic fertilizers used for the experiment. It could be observed that horse dung contains more macro nutrient than pig dung while in all the mineral elements only the value for copper $(323 \mathrm{mg} / 100 \mathrm{~g})$ is higher than that of pig dung. This highlights the importance of horse dung in soil improvement. The table 3 shows that horse dung has higher values with respect to its physical and chemical constituents except for \% sand and potassium (K).This could be responsible for the highest values obtained for all the growth parameters assessed. This finding is supported by Wong, (1985), who reported that higher productivities of tree seedlings were obtained under horse dung treatment than pig dung. Rafiu et al., (2018) also reported similar observations for Tetrapleura tetraptera seedlings in the nursery. Table 4 shows the highest mean value for all the parameters assessed; plant height $(12.49 \mathrm{~cm})$, stem diameter $(0.30$ $\mathrm{cm})$ leaf production $\left(15.69\right.$ and leaf area $\left(134.50 \mathrm{~cm}^{2}\right)$ were recorded in $\mathrm{T}_{2}$ (15 gm of horse dung $+2 \mathrm{~kg}$ of top soil). The least mean values were recorded in the control experiment $\left(\mathrm{T}_{5}\right.$, top soil only); plant height
$(8.25 \mathrm{~cm})$, stem diameter $(0.24 \mathrm{~cm})$, leaf production (9.40) and leaf area $\left(108.06 \mathrm{~cm}^{2}\right)$. With respect to all the mea values recorded, it could be deduced that across the treatments, the effects of $\mathrm{T}_{1}, \mathrm{~T}_{3}$ and $\mathrm{T}_{4}$ were not significantly different from one another $(\mathrm{P}<0.05)$. Which indicates that any of the treatments will present the same or similar plant growth. This result also supported the findings of Rafiu et al., (2018) that $25 \mathrm{~g}$ of horse dung $+2 \mathrm{~kg}$ of topsoil gave the highest performance in terms of height, collar diameter and laef production.

\begin{tabular}{lll}
\multicolumn{2}{l}{ Table 2 Chemical Composition of Pig dung and Horse dung } \\
\hline PARAMETER & HORSE DUNG & PIG DUNG \\
\hline $\mathrm{FE}+\mathrm{t}(\mathrm{mg} / 100 \mathrm{~g})$ & 0.25 & 9.5 \\
$\mathrm{Na}+(\mathrm{mg} / 100 \mathrm{~g})$ & & 320 \\
$\mathrm{MG}+\mathrm{t}(\mathrm{mg} / 1000 \mathrm{~g})$ & 3.75 & 6.5 \\
$\mathrm{Ma}+\mathrm{t}(\mathrm{mg} / 100 \mathrm{~g})$ & & 0.02 \\
$\mathrm{Kt}(\mathrm{mg} / 100 \mathrm{~g})$ & & 38 \\
$\mathrm{CU}++(\mathrm{mg} / 100 \mathrm{~g})$ & 3.23 & 0.3 \\
$\mathrm{~N} \%$ & 1.75 & 2.4 \\
$\mathrm{Pas} \mathrm{P} 04(\mathrm{Mmg} / 100 \mathrm{~g})$ & 3.1 & 180 \\
$\mathrm{Ca}++(\mathrm{mg} / 100 \mathrm{~g})$ & 2.5 & 135 \\
\hline \multicolumn{2}{l}{ Analysis was carried out at the department of Agronomy }
\end{tabular}
University of Ibadan.

Table 3Soil Data; Physical and Chemical Analysis of Result

\begin{tabular}{lll}
\hline S/code & Horse dung & Pig dung \\
\hline $\mathrm{pH}$ & 6.57 & 5.88 \\
Sand $(\%)$ & 84.6 & 94.6 \\
Sand (\%) & 7.8 & 7.8 \\
Clay (\%) & 7.6 & 1.4 \\
$\mathrm{Silt}(\%)$ & 13.1 & 12.3 \\
$\mathrm{Ca}$ & 2.04 & 1.76 \\
$\mathrm{Mg}$ & 0.81 & 0.81 \\
$\mathrm{Na}$ & 0.48 & 0.28 \\
$\mathrm{~K}$ & 0.03 & 0.04 \\
$\mathrm{H}+\mathrm{A}$ & 16.47 & 14.4 \\
$\mathrm{ECEC}$ & 99 & 99 \\
$\mathrm{Base}(\mathrm{Sat})$ & 82 & 72 \\
$\mathrm{C}(\%)$ & 0.35 & 0.21 \\
$\mathrm{~N}(\%)$ & 0.33 & 0.01 \\
$\mathrm{P}(\%)$ & 10.5 & 9.45 \\
$\mathrm{Cu}(\mathrm{mg} / \mathrm{kg})$ & 0.65 & 3 \\
$\mathrm{Zu}(\mathrm{mg} / \mathrm{kg})$ & 0.52 & 0.17 \\
$\mathrm{Fe}(\mathrm{mg} / \mathrm{kg})$ & 26.9 & 4.5 \\
\hline ce: Plant and Fertilizer Laboratory, I.A.R.\&T. (2013).
\end{tabular}

Generally, organic materials are known to modify the soil properties and boost soil nutrient content (Nduka et al., 2009). 
Table 4 Effect of horse dung and pig dung on the growth Naucleadiderrichiiseedlings

\begin{tabular}{lllll}
\hline Treatment & Plant Height $(\mathrm{CM})$ & Stem diameter $(\mathrm{CM})$ & Leaf Production & Leaf Area $\left(\mathrm{CM}^{2}\right)$ \\
\hline T1 & $10.51 \mathrm{~b}$ & $0.27 \mathrm{~b}$ & $12.56 \mathrm{~b}$ & $124.60 \mathrm{~b}$ \\
$\mathrm{~T} 2$ & $12.49 \mathrm{a}$ & $0.30 \mathrm{a}$ & $15.69 \mathrm{a}$ & $134.50 \mathrm{a}$ \\
$\mathrm{T} 3$ & $9.63 \mathrm{bc}$ & $0.26 \mathrm{~b}$ & $10.08 \mathrm{c}$ & $112.27 \mathrm{bc}$ \\
T4 & $10.11 \mathrm{~b}$ & $0.25 \mathrm{~b}$ & $10.36 \mathrm{c}$ & $109.64 \mathrm{c}$ \\
T5 & $8.25 \mathrm{c}$ & $0.24 \mathrm{c}$ & $9.40 \mathrm{c}$ & $108.06 \mathrm{bc}$ \\
L.S.D & 1.81 & 0.02 & 1.59 & 28.48 \\
Grand mean & 10.13 & 0.27 & 11.62 & 117.93 \\
$\% \mathrm{cv}$ & 18.82 & 7.21 & 14.44 & 25.36 \\
\hline \multicolumn{5}{r}{ NOTE: Means with the same letter are not significantly different from themselves. }
\end{tabular}

Table 5 Effect of Horse Dung and Pig Dung on the height growth of Nauclea Diderrichii Seedlings

\begin{tabular}{llllllllllllll}
\hline Treatment & WK1 & WK2 & WK3 & WK4 & WK5 & WK6 & WK7 & WK8 & WK9 & WK9 & WK10 & WK11 & Mean \\
\hline HP10gT1 & 6.67 & 7.33 & 9 & 10.33 & 10.57 & 11.15 & 11.57 & 12.53 & 14 & 14.5 & 14.37 & 15 & 10.15 \\
HP10Gt2 & 8.33 & 9 & 10 & 11.6 & 11.25 & 11.35 & 11.83 & 13.88 & 15.8 & 15.21 & 15.73 & 16 & 12.49 \\
PD10gT3 & 5.33 & 6.23 & 8 & 9 & 9.5 & 10 & 10.93 & 12.47 & 12.61 & 12.84 & 13 & 13.38 & 9.63 \\
PD15gT4 & 6 & 7.5 & 7.5 & 8 & 8.6 & 10.67 & 11 & 11.5 & 12 & 12.5 & 12.43 & 13.26 & 10.11 \\
ControlT5 & 5.57 & 6.7 & 8 & 9 & 9.72 & 10 & 11.85 & 12 & 12.8 & 12.22 & 12.36 & 13.07 & 8.25 \\
\hline
\end{tabular}

NOTE:ns Not-Significant ( $>=.05)$

Table 6 Effect of Horse Dung and Pig Dung on the Stem girth of Nauclea Diderrichii Seedlings

\begin{tabular}{llllllllllllll}
\hline Treatment & WK1 & WK2 & WK3 & WK4 & WK5 & WK6 & WK7 & WK8 & WK9 & WK10 & WK11 & WK12 & Mean \\
\hline & 1.63 & 1.80 & 1.87 & 1.97 & 2.20 & 2.24 & 3.0 & 3.10 & 3.11 & 3.23 & 3.48 & 3.80 & 0.27 \\
HD15gT2 & 1.66 & 1.71 & 2.77 & 2.96 & 3.04 & 3.45 & 3.13 & 3.23 & 3.33 & 3.36 & 3.37 & 3.47 & 0.30 \\
PD10gT3 & 1.66 & 1.71 & 2.7 & 2.63 & 3.3 & 3.5 & 3.7 & 3.9 & 3.15 & 3.20 & 3.24 & 3.28 & 0.26 \\
PD15gT4 & 1.53 & 1.63 & 2.0 & 2.84 & 3.01 & 3.03 & 3.5 & 3.13 & 3.21 & 3.33 & 3.35 & 3.37 & 0.25 \\
Control & 1.52 & 1.60 & 2.0 & 0.24 & 2.78 & 3.1 & 3.03 & 3.6 & 3.10 & 3.17 & 3.21 & 3.28 & 3.30 \\
\hline \multicolumn{10}{c}{ NOTE:** Significant at a level of 1\% probability(,.01) }
\end{tabular}

Table 7 Effect of Horse Dung and Pig Dung on the number of leaves of Nauclea Diderrichii Seedlings

\begin{tabular}{|c|c|c|c|c|c|c|c|c|c|c|c|c|c|}
\hline Treatment & WK1 & WK2 & WK3 & WK4 & WK5 & WK6 & WK7 & WK8 & WK9 & WK10 & WK11 & WK12 & Mean \\
\hline HD10gT1 & 7.5 & 7.67 & 8 & 8.67 & 9.5 & 10 & 10.45 & 11 & 11.5 & 12 & 13 & 14.5 & 12.56 \\
\hline HD15gT2 & 8 & 9 & 10 & 10.2 & 10.5 & 11 & 13 & 14 & 14.54 & 15 & 16 & 17.6 & 15.69 \\
\hline PD10gT3 & 7 & 7.5 & 8.5 & 8.6 & 9 & 10 & 11 & 12 & 12.6 & 13 & 15 & 15.5 & 10.08 \\
\hline PD15gT4 & 6 & 7 & 7.6 & 8.48 & 9.4 & 10 & 10.5 & 11 & 11.5 & 12 & 12.5 & 13 & 10.36 \\
\hline ControlT5 & 5.10 & 5.15 & 6 & 6.5 & 7 & 8 & 9 & 9.5 & 10.8 & 11 & 11.5 & 12.50 & 9.40 \\
\hline
\end{tabular}

NOTE: **Significant at level of $1 \%$ of probability $(, .01)$

Table 8 Effect of Horse Dung and Pig Dung on the Leaf Area of Nauclea Diderrichii Seedlings

\begin{tabular}{llllllllllllll}
\multicolumn{10}{c}{ Table 8 Effect of Horse Dung and Pig Dung on the Leaf Area of Nauclea Diderrichii Seedlings } \\
\hline Treatment & WK1 & WK2 & KW3 & WK4 & WK5 & WK6 & WK7 & WK8 & WK9 & WK10 & WK11 & WK12 & Mean \\
\hline HD10gT1 & 113.33 & 115.63 & 121 & 124 & 125.67 & 127 & 132 & 13.33 & 136 & 139 & 141 & 143 & 124.50 \\
HD15gT2 & 113.7 & 116.3 & 120.7 & 122.7 & 124 & 127.4 & 129.6 & 133.3 & 138 & 139.7 & 142 & 144 & 134.50 \\
PD10gT3 & 166 & 117.7 & 121 & 123.7 & 127 & 128.7 & 130.4 & 133 & 134 & 135.6 & 137 & 138 & 112.3 \\
PD15gT4 & 83 & 74.67 & 110.6 & 123.3 & 124 & 126 & 129.33 & 132.6 & 134 & 136 & 137 & 138 & 109.64 \\
ControlT5 & 80 & 90 & 101 & 123 & 125 & 126.9 & 126.9 & 127 & 128 & 129 & 131 & 133 & 108.06 \\
\hline
\end{tabular}

AYENI, OD; OJO, MO; OKUMODI, BO 
From table 5, results on height of Nauclea diderrichii seedlings shows that plant (seedlings) treated with $15 \mathrm{~g}$ of horse dung $+2 \mathrm{~kg}$ of top soil (T2) had the best performances in height with mean value of $12.49 \mathrm{~cm}$ followed by Treatment one (T1) with $10 \mathrm{~g}$ of horse dung $+2 \mathrm{~kg}$ of top soil, with the value $(10.15 \mathrm{~cm})$ while seedlings with top soil only (T5) showed the least performance in the height value of Nauclea Diderrichii seedlings. With mean value of $8.25 \mathrm{c}$ Nauclea diderrichii has usually been hampered by attacks from orymophoea medioforesta (lepidetera: Noctuae) amd lamprosema. So these specialist insect herbivores can cause serious damages to especially Young plantations of Nauclea diderrichii (Bosu, 2013).From table 6, result on the diameter indicated that plants treated $15 \mathrm{~g}$ of horse dung $+2 \mathrm{~kg}$ of top soil (T2) had best performance in stem diameter with mean value of $0.30 \mathrm{~mm}$ followed by seedlings treaded with $10 \mathrm{~g}$ of pig dung $+2 \mathrm{~kg}$ of top soil (T1) with the value of $0.27 \mathrm{~mm}$ while $\mathrm{T} 5$ produced the least mean value of $(0.024 \mathrm{~mm})$.Attempts to grow Nauclea diderrichii in plantation have generally been hampered by attacks from shown that these specialist insect herbivores can cause damages to especially young plantation of Nauclea diderrichii ((Bosu,2013). From table 7, results on leaf production revealed that plants treated with $15 \mathrm{~g}$ of horse dung $+2 \mathrm{~kg}$ of top soi 1(T2) had the highest leaf production with mean value of $(12.5 \mathrm{cb})$ while T5 produced the least number of leaves (9.40).Apart from timber and service the leaves and bark of Nauclea diderrichii are use in treating several ailments in most rural communities in Ghana and also in preparing soups and serves as a source of fodder for livestock. From table 8, result on leaf area indicated that $\mathrm{T} 2$ had the best leaf with mean value of $\left(113.50 \mathrm{~cm}^{2}\right)$ followed by T1 $(124.60 \mathrm{~cm} 2)$ while T5 had the least performance in leaf area of Nauclea diderrichii seedlings $\left(108.06^{\mathrm{n}} 2\right)$. Analysis of variance table for leaf area indicated that there is no significant difference among the treatments at 5\% level of probability. This implies that the treatment applied toNauclea diderrichii seedlings no significant effect in terms of leaf area.

Conclusion: The result obtained in this study indicated that Nauclea diderrichii seedlings responded best to the treatment of organic fertilizer (horse dung). The treatment with the horse dung showed best increase in height, stem height, leaf production, and as well asleaf area. So, from the data and analysisof the parameter measured in thisresearch it is recommended that horse dung be used for its best response among the treatments for its fast growth of Nauclea diderrichii seedlings. As such, farmers should be encouraged in applying horse dung in planting this seed for the purposes of medicine, nutrition and decoration.

\section{REFERENCES}

Adu-Bredu S; Hagihara A (2003). Long - term carbon budget of the above -ground parts of a young Hioko cypress (Chamaecyparis Obtuse) stand: Ecol Res 18: 165-175

Amishai, S.; Gyampohi, AB.; Sarfoa-Mensah, P.; Qqagrainie, KK. (2009). Livelihood trend in responses to climate change in forest fringe communities of offin basin in Ghana. J. Appl. Sci. Environ. Manage. 13(2) 5-15

Bagch Nadrowski, ML (2010). Diversity and Observation of Medicinal plants in the Bamaa community of the Brong Ahafo region, Ghana.J. Med Plants Research 2: 226 -233.

Bosu,PP; Adu-Bredu,S; Nuto,Y; Kokou, K (2013). Survival, Growth and Orygmophora mediofoveata Shoot borer attack of Nauclea diderrichii Progenesis Established in Three Ecological Zones in Ghana. Open J. Forest 3 (4), 152-158- 15

Burkil, HM (2004). The Useful Plants of West Tropical Africa. Royal Botanic Gardens; Kew http://www.aluka.org

Greenland, CE (1990). The soil physical properties and production the tropic Greshester, John Wiley and son page 52 science Agyemen Uk,

Hansen,, MC; Stehman SV; Potapov PV (2013).High resolution global maps of $21^{\text {st }}$ century forest cover change. Science $342,850-853$.

IUCN, (2009). Red List of Threatened Species 2009 update http://www.iucnredlist.org/

Jackson, JK; Folli G. (1990): Soma results from fertilizer experiments in plantation research paper33 Savannah series.

Manns, U; Bremer, B (2010).Towards a better understanding of inter-tribal relationships and stable tribal delimitations within cinchonoideaes S. (Rubiaceae) Mol. Phylogenetics and Evol 56: 21-39

Nduka, OO; Baiyeri KP; Muoneka CO; Tenkouano A (2009). Impact of the organic and inorganic fertilizers on the post-harvest fruits qualities of 
four Musa (AAB subgroup) genotypes in sub humid Zone of Nigeria. Global J. Agric Sci. 8(2), 185-194.

Niassy S; Diarra K; Niang Y; Niang S; Pfeifer H-R (2010). Effect of Organic fertilizers on the Susceptibility of Tomato lycoperscion esculentum: Solanaceae to Helicoverpa armigera Lepidoptera: Noctuidae in the Niayes Area Senegal. Res. J. Agric. Bio Sci. 6(6): 708-712, 2010

Rafiu BO; Falana AR; Kuforiji E; Obideyi RI (2018). Comparative effect of brewers spent grain and horse dung on the growth of Tetrapleura tetraptera Shum and Thonn seedlings. Inter. J. Agric. Environ. Biores. 3 (6) 352-359.
Smith J; Scherr SJ (2002). Forest Carbon and Local Livelihoods: Assessment of Opportunities and Policy Recommendations. CIFOR Occasional Working Paper No. 37. CIFOR, Bogor, Indonesia, p. 56.

Wong, MH (1985), Effects of animal manure composts on tree (Acacia confusa) seedlings growth. Agric. Wastes. 13 (4) 261-272. 